\title{
BRIEF SCRUTINY OF THE HEGELIAN ONTO-LOGIC: THE UNBEGUN IDENTITY OF BEING AND NOTHING AS UNSAYABLE PASSING OF IDENTITY AND DIFFERENCE IN BECOMING
}

\author{
Horațiu M. Trif-Boia \\ PhD., Post-Doctoral Researcher, Babeș-Bolyai University Cluj-Napoca, ROUMANIA, \\ trif.horatiu@ubbcluj.ro
}

\begin{abstract}
In the process of Logic's and Metaphysics' education, the fundamental principle that has to be grasped as an implacable prerequisite, is the principle of identity. The principle has two fundamental instantiations: the formal one and the non-formal one. The choice for one or the other has implications regarding the very propaedeutic of the educable since he cannot devise any ultimate meaning of this principle, especially in Metaphysics, if the educable does not begin to thematize the very transformation of his/her own thought by the mutations that the rethinking of this principle supposes. Therefore, Hegel is our choice in this matter since he is the thinker who, by definition has conceived this matter as a question of subject and object coincidence, thus, any change that the object incurs, is already inscribed in the inner economy of the subject's thought too. As a consequence, our discussion will take into consideration only the speculative variant of the non-formal actualizations of the identity principle, and we shall not discuss G. Priest's dialetheism that we reject. Hegelian methodology is, thusly, substantiated by the very endeavor of thinking the issue of the concepts that are taken into consideration - there is no difference, for Hegel, between the method of arriving at the object of research and the object; the method is the object, and the object is the method because they are the very paths that reveal the inner power of reflection and the substance of the conceiving subject: in Metaphysics the subject conceives himself, and this activity is the very object and the very method that are scrutinized.
\end{abstract}

The coincidence between subject, object and method are to be discussed from a propaedeutic point of view in another paper. In the present paper we shall only discuss the principle of identity which is here to be taken into consideration in its first fundamental occurrence, that of metaphysical Ontology as it is engaged by Hegel in the Science of Logic. We shall hereby discuss the problem of the originary thinking by Hegel of Being, Nothing and Becoming. In the economy of Hegelian thought these instantiations and their speculative dialectics are engaged by the implicit supposition of a non-formal principle of identity. Though the proper instantiation of the principle of identity is discussed by Hegel in his second part of the Science of Logic (the chapter of Essence), this occurrence is decisively settled with the beginning of the first chapter of the Science of Logic (Being) where Hegel initiates the beginning of philosophy as beginning of thinking; and the beginning of thinking is discussed as absolute ontological beginning. Therefore, in a swift analysis we are hereby clearing a few aspects concerning the Hegelian ontology and its suppositions towards the identity principle. Is Being correctly assumed as purely abstract and void of determinations? Is Being coincidentally postulated as identical with Nothing? Is there a superior unity between Being and Nothing? Is Being's and Nothing's difference an ontological irreducible difference? What is Becoming? The conclusions to these questions should be illuminating not only for the philosopher, but for every human being that has the conscience of his/her own existential issues under the pressure of the unknown.

Keywords: Hegel, principle of identity, Ontology, Metaphysics, Propaedeutic, Science of Logic. 


\section{SPECULATIVE PROPEDEUTICS AS MOMENT OF INNER REALISATON}

When school classes endeavor in transmitting knowledge to young generations, there is always an occurrence of the issue of lack of motivation among at least a part of the students involved. Motivation is linked to desire and desire corresponds inside what was called the tripartite structure of the human subject - which comprises the Real, the Symbolic and the Imaginary (Lacan J., 2001, pp. 323-328) - to the imagination, both as a part of the Symbolic and as the Imaginary itself.

The human subject in general experiences a profound need to realize within their own self the work of apprehending the fundamental meanings of existence. School activities are one of the chief opportunities to attain this need, therefore every student is usually fundamentally challenged by the meanings vehiculated in the educational process. The scope of the education may not be realized but by revealing the inner deep and essential signification of the encountered facts, and only then has the subject access to the opening of understanding with a certain precision what one is supposed to engage into the acts of his or her own defining existence. Without this inner revelation of one's own structuring of thoughts, without the thoughts being integrated in the most intimate intention of the subject, the educational process is doomed to fail.

The reason for this failure is that whatever is significantly and meaningfully apprehended and internalized by a subject has this position only because it has an important role in the goals and definition of oneself, it has become a central element in the realization of one's own being and character. And such importance, beyond the mere individual inclinations that may or may not arise within the horizon of the subject, can be and not seldom is dictated by the objective structure of the meanings or facts that the subject relates to. However, in order to attain such position, that of a consequential element, the endeavor has to make the object or the medium of a meaningful experience. Meaningful experiences are situations where the self of the subject is facing transformative events that occur a challenging mirroring of the self, offering the place where a split presentation of the self needs the regaining of its inner transfigured identity as it has been modified by the element that has produced the split and compelled its need to regain its identity (Lustman, 1977; Lacan J., 1966, pp. 666-667, 793-827).

In this regard two issues are capital: the identity that the self initially has, the split that occurs and the regain of the identity that also contains the negative experience that has been acquiesced and dealt with in a positive and transcending manner. The position and relations that we acknowledge for these three elements and their ontological structures and roles is fundamental and gives the entire process of meaningful subjective experience its entire substance and engages it on a soteriological beneficial opening or it blocks it under the weight of confusing and false representations about the subject and his or her inner life (Hegel, 2018 [1807], pp. 4-6).

In this respect, the speculative method that was thought and put to work by Hegel in his philosophy might give us an operable solution for the engagement in meaningful experiences that are cardinal in the arousal of the desire for involvement in the process of molding the self. The Hegelian position in this respect is that in the fundamental experience of the subject the three elements or moments of the inner experience must find the place where they are revealed to coincide. Thus, if in every other human endeavor method and object or proper activity are different, in the realm of metaphysics the method which is the way of the subject or which constitutes the position of the subject, becomes the object or the system itself (Opiela, 1983, pp. 39-51; Hegel, 2018 [1807], pp. 9-14).

But, as we saw Hegel saying, this method must face its own negativity or mediation in order to attain its proper thrust and to realize its object which is itself. The negativity that is supposed here to be accepted as already engendered within the structure of the subject must match the challenge of the identity that is sought because the subjectivity cannot suppose as its own essence the pure continuity of existence: the subject is defined by its own inner fundamental absence as determinate instance. Or, as Lacan puts it:

Bref quand Daniel Lagache vient au plus près à dire que « cette absence du sujet cohérent caractérise le mieux l'organisation du Ça », nous dirions que cette absence du sujet qui dans le Ça inorganisé se produit quelque part, est la défense qu'on peut appeler naturelle (...).

Cette place est celle même où toute chose est appelée pour y être lavée de la faute, que cette place rend possible d'être la place d'une absence : c'est que toute chose puisse n'exister pas. Par cette matrice si simple de la première contradiction, être ou ne pas être, il ne suffit pas de constater que le jugement d'existence fonde la réalité, il faut articuler qu'il ne peut le faire qu'à la relever du porte-à-faux où il la reçoit d'un jugement d'attribution qui s'est déjà affirmé. 
C'est la structure de cette place qui exige que le rien soit au principe de la création, et qui, promouvant comme essentielle dans notre expérience l'ignorance où est le sujet, du réel dont il reçoit sa condition, impose à la pensée psychanalytique d'être créationniste, entendons de ne se contenter d'aucune référence évolutionniste. Car l'expérience du désir où il lui faut se déployer, est celle même du manque à être par quoi tout étant pourrait n'être pas ou être autre, autrement dit est créé comme existant. (Lacan J., 1966, pp. 666-667)

Thus, every instance of true and effective knowledge is organized within the subject by engaging the concepts of absolute beginning as absolute immediate identity that is immediately put in its own negation (Übergehen in Anderes), essential development of the inner structure of the elements involved as inner selfdivision and pure variation of its own pure reflected passing (Wesen) in order to culminate in the identity of all the given reflected variations as regain coincidence between the initially immediately reflected identity and its immediately negative variations in the Concept (Begriff) (Léonard, 1974, p. 38; Biard, et al., 1981, pp. 24-31; Hegel, 2010 [1832], pp. 38-43).

Taking into account the imposed limits of the present study, we shall hereby confine ourselves to a short analysis of the initiation of immediate knowledge which is entirely engaged through the discussion around the immediate and absolute Beginning and, thus, of immediate and absolute Being. Of great interest to us is the issue of immediate and absolute self-differentiation of Being: the origin of negativity or of discontinuity is the main immediate incision the appraisal of which is to be made if we are to open the trial of understanding the origin of what Lacan called the Symbolic and its signifier or their supporting living vehicle who is the subject as inner movement and need of achievement.

\section{IMMEDIACY AND (UN)BEGINNING}

As Hegel remarks (Hegel, 2010 [1832], p. 45) there is a great logical and ontological difficulty in conceiving and making an absolute Beginning of everything, such as a rigorous science requires. The Beginning is either immediate, either mediated and, Hegel says, it is very easy to show that in can be neither because the two variants are simultaneously incompatible and self-contradictory:

If one is to begin with pure immediacy, then this immediacy rejects by its very definition and nature any possibility of an other, of an alterity or difference. Moreover, if we are to introduce difference within it, we couldn't find any source of it since there is nothing else but this pure and absolute immediacy, taking into account that we are speaking about the absolute and pure Beginning of everything and, thus, it is already given in this concept that we are forbidden to make any other supposition of any other element or existence prior or collateral to pure unbegun immediacy. But even we supposed dogmatically that this difference would be assured or given to us somehow, we could not have any operational ground to apply it in order to affect the pure and absolute unbegun immediacy. Because purely, absolutely unbegun immediacy has no difference, it also means that it has no parts or detectable features or even areas, at all. There is no given manifestation or surface or detectable beginning (detection supposes differentiation, thus already given beginning) where we could or should apply our given or supposed difference in order to differentiate or to begin something within the unbeginning. In fact, we can easily perceive that unbeginning is unperceivable or undetectable because it is purely and absolutely confined and sealed within its absolute immediately shutting which is foreclosed absolutely prior to everything, thus even prior to itself; prior to itself since there is no self, thus, there is nothing to shut down, not even the shutting in itself, but that is precisely why the immediate and absolute shutting is already given as exhaustively realized before its own proper and abrupt realization. It is an abruptness that is abruptly suppressed and foreclosed as its own sudden foreclosure towards its own givenness.

On the other hand, the Beginning cannot be understood as mediated either. Mediation already supposes differentiation, thus it is absolute and pure beginning already abruptly given. However, mediation is precisely what gives the Beginning in itself. Which means that it is the very mediation that needs to be open in the sealing of the absolute Unbeginning, so that mediation is absolutely essential for the constitution of the account concerning the Beginning in itself. But it is precisely the passing from absolute immediacy to mediation that needs to be accounted for at this point of the narrative upon the Origin, and mediation cannot be taken as given because its proper resulting has not been grounded in immediacy which is exclusively its opposite, but only postulated as a pure dogmatic result.

Having acquired the evidence of this inescapable onto-logical impossibility of imposing mediation as something external to the originary pure immediacy, Hegel chooses to advance on the premises of pure immediacy as such:

The true expression of this simple immediacy is therefore pure being. Just as pure 
knowledge should mean nothing but knowledge as such, so also pure being should mean nothing but being in general; being, and nothing else, without further determination and filling. (...)

The beginning must then be absolute or, what means the same here, must be an abstract beginning; and so there is nothing that it may presuppose, must not be mediated by anything or have a ground, ought to be rather itself the ground of the entire science. It must therefore be simply an immediacy, or rather only immediacy itself. Just as it cannot have any determination with respect to another, so too it cannot have any within; it cannot have any content, for any content would entail distinction and the reference of distinct moments to each other, and hence a mediation. The beginning is therefore pure being. (Hegel, 2010 [1832], pp. 47-48)

A few paragraphs further, Hegel makes the point that every beginning is always abstract and devoid of content, such that only the following development of that initial abstractedness can account for true knowledge (Hegel, 2010 [1832], p. 49). This is the conclusion that he entails to the argument that he develops within the same pages through which he shows that (Biard, et al., 1981, pp. 39-41):

1. We cannot account for the initial immediacy as being the ground of what follows since the ground is already taken as mediated because grounding supposes the activity of justifying reason - thus, it supposes mediation. But the ground, in this metaphysical ontology, can only be considered as a result. Therefore, the ground cannot be considered as the same with what is prior, as true and absolute Beginning. It would be implicit that Being is not the ground, at least not in the sense of a justifying reason.

2. Therefore, the pure Beginning cannot speak of pure Being as of the ground upon which everything else rests, although there is no other instance from which the development and any result could be set out.

3. But in this, the ground, as mediated and developed result, coincides with the undeveloped and unjustified immediacy of Being because the entire reason with all its justifications is a development and a mediated result of the initial and void point of ontological priority that is Being. In this respect, the entire movement of knowledge and of existence is revealed as returning to its own ground as result; and this is the turning point for the methodology of any subject that endeavors in the analysis of metaphysical fundamental principles: he or she cannot suppose instances or elements that are foreign or prerequisite to the analysis, the analysis is driven by its own immediacy and every element that is engaged in it has to result from this immediacy only.

Resuming the issue of the relation between mediated and developed result and the undeveloped and unjustified immediacy, it all sets out from the well-known relation where what is prime and abstract is precisely undeveloped ground too because it consists in the initial void or instance which comes to be determined itself further through its own fundamental mediated differentiation and development:

Conversely, it follows that it is just as necessary to consider as result that into which the movement returns as to its ground. In this respect, the first is just as much the ground, and the last a derivative; since the movement makes its start from the first and by correct inferences arrives at the last as the ground, this last is result. Further, the advance from that which constitutes the beginning is to be considered only as one more determination of the same advance, so that this beginning remains as the underlying ground of all that follows without vanishing from it. The advance does not consist in the derivation of an other, or in the transition to a truly other: inasmuch as there is a transition, it is equally sublated again. Thus the beginning of philosophy is the ever present and self-preserving foundation of all subsequent developments, remaining everywhere immanent in its further determinations. (Hegel, 2010 [1832], p. 49)

With this, the Hegelian premise of identifying Being at the same time with that which is pure, void, immediate and abstract Beginning and with that which is developed, full, mediated and concrete result, is already put to work and logically founded. Moreover, the beginning of knowledge through the considerations concerning pure Being is fundamentally legitimized, and therefore beginning with pure Being is not something contingent anymore. With this, Hegel says, it is evident already that what is pure and abstract lack of content because it is absolute immediacy, is already absolutely mediated result. That which is given as the absolutely prior is always present as sublated (Aufhebung) within the content of what is developed; and that which is found as the true reason of the entire development of being and thinking as its culminated end in itself, is already the ground that makes possible the entire movement of development. With this, the absolutely pure immediacy is seen as being exhaustively given as self-mediated in itself through its coincidence with its own terminative suddenness: 
So we have just given, right within science itself, the reason why in pure science the beginning is made with pure being. This pure being is the unity into which pure knowledge returns, or if this knowledge, as form, is itself still to be kept distinct from its unity, then pure being is also its content. It is in this respect that this pure being, this absolute immediate, is just as absolutely mediated. (Hegel, 2010 [1832], p. 50)

At this moment it would appear that Hegelian metaphysics would return simply at the methodology and concepts of the old metaphysical ontology. This would be a mistake, a mistake that becomes ever more apparent when we understand that there is still a tacit tension remaining between the two concepts that have been linked above, that of the pure and absolute Beginning and that of pure and absolute Being. Further Hegelian analysis of the tension reveals that they might not suppose each other exclusively, though they are indispensable to one another.

\section{BEGINNING WITHOUT BEING? OR THE UNITY OF BEING AND NOTHING IN BEGINNING}

Arrived at this point, it becomes clear that the determination of Being can also be put aside when speaking about the absolute and pure Beginning of everything. This can also be seen as an epistemological and gnoseological necessity since any collapse of knowledge into pure Being would result in the abstract and, thus, negative result of not being able to determine itself further (Hegel, 2010 [1832], p. 50).

However, there also must be put to work the supposition of pure Beginning without supposing Being either:

But, it may be said, the determination of being assumed so far as the beginning can also be let go, so that the only requirement would be that a pure beginning should be made. Nothing would then be at hand except the beginning itself, and we must see what this would be. This position could be suggested also for the benefit of those who are either not comfortable, for whatever reason, with beginning with being and even less with the transition into nothing that follows from being, or who simply do not know how else to make a beginning in a science except by presupposing a representation which is subsequently analyzed, the result of the analysis then yielding the first determinate concept in the science. If we also want to test this strategy, we must relinquish every particular object that we may intend, since the beginning, as the beginning of thought, is meant to be entirely abstract, entirely general, all form with no content; we must have nothing, therefore, except the representation of a mere beginning as such. (Hegel, 2010 [1832], p. 51)

The speculative reason of this turn is that it could be assumed that even pure and absolute Being is an unwarranted supposition dogmatically given in spite of the scientific request that nothing should be put or supposed prior to the Beginning. Being, as pure presence, even if absolutely abstract or undetermined or as pure immediacy, could still be seen as something, and thus as an immediacy that is yet mediated by relation either to itself, either to the absolute void or nothingness. But the pure and absolute Beginning cannot suppose any kind of something, be it even under the form of any relation, the relation towards itself included.

Even here Hegel avoids putting the issue in the terms of a pure and absolute Beginning departing from absolute Nothingness:

As yet there is nothing, and something is supposed to become. The beginning is not pure nothing but a nothing, rather, from which something is to proceed... (Hegel, 2010 [1832], p. 51)

The reason is that the Hegelian methodology is speculative and specularity of reason is defined in the first place by always taking into consideration all and every element of a given situation or state of fact: thus, in every logical or ontological situation, reason always supposes both identity and difference since they always suppose each other by their inner correlative definition - and this is going to be the Hegelian position at every step of his system:

Here we may quote from it only this, that there is nothing in heaven or nature or spirit or anywhere else that does not contain just as much immediacy as mediation, so that both these determinations prove to be unseparated and inseparable and the opposition between them nothing real. (Hegel, 2010 [1832], p. 46)

It would not be difficult to demonstrate the unity of being and nothing in every example, in every actual thing or thought. The same must be said of being and nothing as was said 
above of immediacy and mediation (which contain a reference to each other and hence negation), that nowhere on heaven or on earth is there anything which does not contain both being and nothing in itself. (Hegel, 2010 [1832], p. 61)

That is why Hegel insists, a few chapters further, that the main and fundamental tenet in thinking the abstractedness of pure Beginning and of everything that results from it is to be considered as both Being and Nothing in their unsayable (unsagbar) difference to each other (Hegel, 2010 [1832], p. 68) that opens in their mutual result as Becoming (Werden) and that the gravest mistake in metaphysics is to enclose thinking in a one dimensional or one determinateness aspect of relating to the real - limiting the entire horizon either to Being only, either to Nothing only; reason that causes Hegel to insist on the absolute lack of any difference between pure Being and pure Nothing. But this limitation to one-sidedness is doomed to foreclose definitively the entire multiplicity or richness of being and of existence.

In our case, it would mean that mere Nothing, taken bare as exclusive instance of what should beget Beginning, is incapable to account for this burden because of its own void of content, and being barren, it can only forestall its own instantiation not even being able to engage towards any activity and least of all activity that would yield an other - a situation that repeats the foreclosure of pure Being without Nothing, that itself cannot generate anything either:

Ex nihilo, nihil fit - is one of the propositions to which great significance was attributed in metaphysics. The proposition is either to be viewed as just a barren tautology, nothing is nothing, or, if becoming is supposed to have real meaning in it, then, since only nothing comes from nothing, there is in fact none in it, for the nothing remains nothing in it. Becoming entails that nothing not remain nothing, but that it pass over into its other, being. (...) ... no matter how synthetically or merely imaginatively it took this proposition, there is yet even in the most incomplete unification of being and nothing a point at which they meet, and their distinguishedness vanishes. - The proposition, nothing comes from nothing, nothing is just nothing, owes its particular importance to its opposition to becoming in general and hence also to the creation of the world out of nothing. Those who zealously hold firm to the proposition, nothing is just nothing, are unaware that in so doing they are subscribing to the abstract pantheism of the Eleatics and essentially also to that of Spinoza. The philosophical view that accepts as principle that being is only being, nothing only nothing, deserves the name of "system of identity"; this abstract identity is the essence of pantheism. (Hegel, 2010 [1832], p. 61)

Nothing can begin, either in so far as something is, or in so far as it is not; for in so far as it is, it does not begin to be; and in so far as it is not, it also does not begin to be. - If the world, or anything, had begun, it would have begun in nothing; but in nothing there is no beginning - or nothing is not a beginning; for a beginning implies a being, but nothing contains no being. Nothing is only nothing. In a ground, a cause, and so on, if this is how nothing is determined, there is contained an affirmation, being. - For the same reason, too, something cannot cease to be. For then it would have to contain nothing, but being is only being, not the opposite of itself. (Hegel, 2010 [1832], p. 79)

But if this is the fundamental supposition of the Hegelian speculative reason, that there is an absolutely prior identity between identity and difference or, ontologically, between Being and Nothing, then two problems arise:

1. The question of absolute originary ontological difference - how and where is this ontological difference given in the priority of the unbeginning, where is it supposed to spring from? This can be explained as follows:

The question of the ontological absolute priority of the unbegun originary - since Being and Nothing, identity and difference are postulated as coincident in their fundamental instantiation as absolutely passing one into the other, their unity has to be the effect of their originary unbegun indiscernibility. What and how is this common Origin of Being and Nothing? Moreover, if this Origin is followed by the instantiation of Being and Nothing as distinctively given in order for them to have had already passed one into the other, thus they are simultaneously indistinct but different from each other, then this Origin is also the absolutely undetermined spring of their difference (Biard, et al., 1981, p. 57). Is this just another repetition of the duality of Being and Nothing, are Being and Nothing in their simultaneous indistinction their own proper Origin as immediacy in itself, or is the Origin a supreme immediate transcendence beyond the separateness of Being and Nothing? Then, of course, this issue also can be developed as a separate discussion concerning another aspect: if 
there is coincidence between Being and Nothing in the Origin, is this Origin beyond the activity of Becoming? Does it have any rest as Schelling accused Hegel? (Schelling, 1994 [1827], p. 160; Bowie, 1993, pp. 175176; Wirth, 2003, p. 17) The problem is double:

First, Hegel pretends that there is no real difference between Being and Nothing, their originary coincidence being the ground of the speculative depart of metaphysics. But this lack of difference already engages the issue of the undivided Origin on one hand, because their lack of difference is precisely this originary coincidence manifest in their concept (Schlitt, 2012 [1984], p. 33). On the other, this lack of difference is itself also, as a second aspect, a result of the originary difference that keeps them separate in order for them to pass one in the other. Their unsayable difference which is their prior undivided Origin is what unites them without distinction and a unity that manifests as their perpetual passing one in the other, which cannot happen without their prior real distinction.

Second, the distinction that makes possible the separation of Being and Nothing in order to unite them simultaneously in order to open up in the order of Becoming that springs determinate being, is not defined in Hegel. Or, rather this distinction is named by Hegel himself as "unsagbar", that is "unsayable" (Hegel, 2010 [1832], p. 68); or, ineffable, to translate it differently. Thus, the very essence of the absolute ontological manifestation passes as impossible to be named, thus, impossible to be assigned, apprehended, defined.

Thus, we can see that Hegel himself plays, maybe unconsciously, with the double instantiation of the Origin: on one hand, as pure Difference or Difference as Difference (Unterschied an Sich), it is not manifest, but ineffable transcendence of what lies beyond the manifest and the activity of the manifestation given as Being and Nothing, and it is the ground of their difference that maintains their distinction as basis of their reciprocal coincidence that amounts to absolute identity as Becoming; on the other, the Origin is itself manifest as One, but a One that is already divided within itself as Being and Nothing, but this division also reveals their absolute lack of distinction, their absolute unity, but as Becoming, thus, as absolute activity (Schlitt, 2012 [1984], pg. 34-35).

2. The question of the reformation or reformulation of the principle of identity - once that the fundamental supposition of metaphysical ontology is the intimate and originary coincidence between identity and difference, this has infinite and decisive consequences both in ontology and logic.

It is the place to observe that the first issue epitomizes the essence of the Hegelian philosophy and it tacitly supposes a speculative reformation of the identity principle as ineffable and immediate absolute differentiation in itself of the absolute immediacy as immediate passing of itself.

\section{BEING, NOTHING, BECOMING: REFORMING THE IDENTITY PRINCIPLE}

There are two fundamental aspects of the relation between Being and Nothing (Biard, et al., 1981, pp. 4751): their immediacy and their pure identity to one another through their very definition.

Pure Being (reine Sein) is thought beyond every determination. As Spinoza put it, every determination is limitation, thus, negation (Spinoza, 2002, p. 892). Thus, one would expect that Being would be treated by Hegel under the conceptual realm of the affirmative and of pure, undetermined presence. But because Being is also purely immediate (Hegel, 2010 [1832], p. 58) or, since this is the unassuming moment of pure and absolute Beginning that cannot suppose anything prior to itself, Being is the absolute Immediacy in itself (Schlitt, 2012 [1984], pg. 30-31), Hegel understands its lack of determination as pure void:

In its indeterminate immediacy it is equal only to itself and also not unequal with respect to another; it has no difference within it, nor any outwardly. If any determination or content were posited in it as distinct, or if it were posited by this determination or content as distinct from an other, it would thereby fail to hold fast to its purity. It is pure indeterminateness and emptiness. - There is nothing to be intuited in it... (...) Being, the indeterminate immediate is in fact nothing, and neither more nor less than nothing. (Hegel, 2010 [1832], p. 59)

Pure Nothing (reine Nichts) is also thought as simple, equal to itself, empty, absence of determination, content and of any distinction within. Conforming to the theological tradition, Nothing would have had to be thought as pure and absolute splitting in itself, inequality to itself, absolutely distinct from itself in pure emptiness. But such a Nothing would not be consistent with the position of pure and absolute unbegun (unassuming) Beginning. First, Beginning is difference, but it does not mean necessarily splitting and inequality. Second, it is not clear where would this splitting and inequality come from since it would be the absolute opposite to the lack of distinction that can be found in Being. Thus, the Hegelian postulate of Nothing is not the meontological occurrence of the derivate void (nor the infernal variant of it). Instead of 
being the oủx óv, the Hegelian immediate Nothing seems at first glance to be just a game of words where Hegel names the pure Origin of the Beginning with another name, but preserving the same description of it - although, Hegel does seem to return to the classic meaning of the Nothing a few pages later (Hegel, 2010 [1832], p. 60) where he speaks about "abstract, immediate negation" and "negation devoid of reference".

However, there appear two operations:

First, Hegel accentuates the concreteness of Nothing in order to postulate its being

In so far as mention can be made here of intuiting and thinking, it makes a difference whether something or nothing is being intuited or thought. To intuit or to think nothing has therefore a meaning; the two are distinguished and so nothing is (concretely exists) in our intuiting or thinking... (Hegel, 2010 [1832], p. 59)

Second, both Being and Nothing are given the ontological distinction from one another in the third paragraph of the opening of the speculative movement of Being and Nothing only in order to make them identical in their mutual passing one into the other as Becoming (Werden). Since they have been described as identical, it would mean that, in fact, we assist here to only one instance of the absolute Origin given in its two aspects through which it expresses itself as purely differing in itself and passing from itself into itself as pure and absolute movement or activity of absolute passing. - We could ask at this point if it really is any distinction between the caesura by which the absolute unbegun and non-manifest Origin manifests itself as pure Being, pure Nothing and their passing one into the other as Becoming, and "the abstract, immediate, devoid of reference negation" that Nothing is. Hegel gives no indication contrary to what he continually assumes as a pure, immediate and absolute coincidence between the unbegun Origin, Being, Nothing and Becoming as their passing.

This absolute passing culminates, also, in the calm and absolute "vanishedness" of itself (eine solche Vereinigung aber zerstört sich), which could also be translated as "destruction of itself"; this result is not the immediate Nothing from the Beginning, but "quiescent simplicity" as being that is passed into existence as expression of concrete and definitive passing into one another of Being and Nothing:

This result is a vanishedness, but it is not nothing; as such, it would be only a relapse into one of the already sublated determinations and not the result of nothing and of being. It is the unity of being and nothing that has become quiescent simplicity. But this quiescent simplicity is being, yet no longer for itself but as determination of the whole. (Hegel, 2010 [1832], p. 81)

Thus, we could find in the Hegelian movement, seen in its whole, as the expression of absolute Immediacy, postulated as Origin or ground of Beginning, that gives itself as pure undetermined coincidence of passing in itself. The passing, in order to occur, needs the two instances of Being and Nothing that are described as identical, though they are required to be, at the same time, distinct from one another. The great issue here is that the origin of this distinction between them is not properly discussed by Hegel, but with the sole purpose of denying it, although he makes the very clear utterance of their real difference and separation:

But the truth is just as much that they are not without distinction; it is rather that they are not the same, that they are absolutely distinct yet equally unseparated and inseparable, and that each immediately vanishes in its opposite. (Hegel, 2010 [1832], p. 60)

Their mutual difference seems to be lost as not ever have been manifest since their pure occurrence coincides immediately with their passing one into the other without ever having been given their distinction as something actual or effective. The immediate, sudden exhaustion of their simultaneous passing into one another already prior to their own passing (nicht übergeht, sondern übergegangen ist), seems to cover definitively any trace of their actual distinction:

The truth is neither being nor nothing, but rather that being has passed over into nothing and nothing into being - "has passed over," not passes over. (Hegel, 2010 [1832], pp. 59-60)

This distinction is then openly and emphatically rejected by Hegel for the course of Remarks 2 (especially) and 3 (in passing) following the speculative dialectics of Being and Nothing (Hegel, 2010 [1832], pp. 66-78). The scope of these Remarks is to make the necessary corrections and observations concerning the possible interpretations of his speculation concerning Being and Nothing.

In Remark 1 Hegel insists upon, first, the effectivity of the concept of Nothing which is to be held as expressing a real referent; second, upon the culmination of the unity of Being and Nothing in the immediate movement of Becoming and that this unity is to be found in the natural languages and traditional representations about the world and the life or in the traditional theology, especially Christian. Concerning 
theology, Hegel's considerations about the presence of alterity in God's works and attributes are notable since it again serves as an example that he does not understand Nothing as oủx óv. Just as significant are his somewhat ironic criticisms against the Kantian objection against the Ontological Argument where Hegel emphasizes the Kantian confusion, on one hand, between what is determinate and what is not; on the other hand, between the determinacies' position, where determinate being and determinate nothing appear to contradict and eliminate each other, and the pure and absolute abstractions of Being and Nothing where their coincidence is apodeictical - hereby giving a powerful counterargument against Kant's assertion that the Prototypon transcendentale is contradictory, hence, only an asymptotic ideal, since the Absolute, as Totality, would entail the contradictory superposition between all attributes or predicates and their negations, such superposition being ideally possible at most (Kant, 1998 [1781], pp. 553-559).

In the second Remark Hegel begins by emphasizing the difference between Being and Nothing. But at the same the immediate and simultaneous unity of the two is also given by their very distinction — thus, Hegel says

Now, in so far as the proposition "being and nothing are the same" expresses the identity of these determinations, yet in fact equally contains the two as distinguished, it internally contradicts itself and thus dissolves itself. And if we concentrate on this result, what we have before us is a proposition which, on closer inspection turns out to vanish spontaneously. It has movement. But in thus vanishing, it is its proper content which comes to be in it, namely becoming. (Hegel, 2010 [1832], pp. 66-67)

Hegel continues then the considerations about what the speculative proposition means: taking into consideration, simultaneously, the inadvertence of subject and object in any judgment of the intellect and the fact that, in speculative propositions, the non-identity of subject and object are an essential moment too. In order to correct this lacking, the opposite judgment is then expressed which affirms the opposition of Being and Nothing, but the defect in this case reveals to be the disconnection between the two propositions which are, in fact, not only connected, but expressing the same truth and, thus, united absolutely. This union, Hegel says, is "an unrest of simultaneous incompatibles, a movement". But the most important issue here is that the unity that is postulated between the two elements is derived from a comparison that, as an operation that pertains to the external reflection of a subject, supposes the neutral indifference between two instances of a "totally abstract sameness" established by a comparison. Of course, since the two elements postulated as identical are contradictory one another, this identity sounds "harsh and discordant"; the solution cannot be using another word, though - "unseparatedness" or "inseparability", because then the affirmative aspect of the connection is lost and the speculative method is dissolved. The conclusion is instructive and represents the edifice upon which Hegel rests his entire speculative edifice since it obviously is the attempt at the reformation of the identity principle as a result of the analysis of the pure and absolute Beginning and the consequences that can be derived from it:

So the whole true result that we have here before us is becoming, but a becoming which is not the merely one-sided or abstract unity of being and nothing. It consists rather in this movement, that pure being is immediate and simple and for that very reason is just as much pure nothing; that the distinction between them is, but equally sublates itself and is not. This result does also assert, therefore, the distinction of being and nothing, but it asserts it as one which is merely intended. (Hegel, 2010 [1832], p. 68)

At this very point, in denying the one-sided attitude of formal thinking that tries to keep separate the two elements of the speculative identity, Being and Nothing, Hegel also engages, somehow against his proper intentions, in revealing the transcendent character of the difference between Being and Nothing and in this he is also revealing the actual source of their identity and manifestation as pure and absolute speculative Origin that has no presupposition in itself and that differentiates itself in itself prior to itself:

The ordinary assumption is that being is the absolutely other of nothing, and that there is nothing as clear as this absolute distinction; indeed, nothing seems easier than being able to state it. But it is just as easy to convince oneself that this is impossible, that the distinction is unsayable. Let those who insist on the distinction of being and nothing, let them just try to state in what the distinction consists. If being and nothing had any determinateness differentiating them, then, as we said, they would be determinate being and determinate nothing, not the pure being and the pure nothing which they still are at this point. Their distinction is therefore completely empty, each is as indeterminate as the other; the distinction depends, therefore, not on them but on a third element, on intention. (Hegel, 2010 [1832], p. 68) 
The factual truth of the relation of Being and Nothing is, then, their unsayable unity and differentiation in the unbegun Origin which they explicit in their manifestation as simultaneous identity-difference that sublates itself into Becoming - there is no independent subsistence of Being or Nothing from one another, and a few lines further Hegel formulates explicitly their position each as pure "transition of the one into the other". Becoming is, then, the ultimate revelation of the absolute identity of the Origin, it is its final manifestation as absolute undetermined immediacy, after which only determined being follows. If we were to express this as a syllogism, the Origin is, then, that which keeps itself as non-manifest or unthought, or the subject that inhabits the major premise, while Becoming is its manifestation in the plenitude of the ontological instantiations, thus, the identity of subject and predicate in conclusion, while the identity-difference of Being and Nothing is expressing as minor premise the tacit identity-difference between Origin and Becoming as the middle term of the entire syllogism and as condition for the actualisation of the Origin as absolute Becoming.

\section{CONCLUSIONS}

Identity is reformed in Hegel not only by being postulated as a speculative coincidence of opposites, which amounts to a formal contradiction for the intellect, but especially by immediately self-dividing itself as pure and absolute immediacy and remaining immediately identical in this division within the unbegun Origin. But the objection that would need to be raised against Hegel would be that identity is postulated as "abstract" and "void" - as such, it would entail content, either under the concept of transmuting the content into its abbreviation (abstraction), either under the concept of eliminating, draining or depleting the content once given. - Following Hegel's own reasoning, abstraction and void are results and look as the opposites of the elements from which they are obtained.

But the unbegun identity cannot suppose either an abstraction, either the void since it provides no element the transmutation or elimination of which would result into either of these two positions.

Moreover, the immediate and factual movement of the absolute Immediacy - as unbegun Origin into the Beginning as reciprocal passing of Being into Nothing and viceversa as resulting into Becoming - implies a "rich" Immediacy, an exceedance of the absolutely prior given, of the purely self-divided unified indivision. The "richness" does not have to mean the presence of a content: it can be seen just as the ineffability of the exceeding priority upon itself of the pure and absolutely sudden Immediacy.

From this point of view on, we can assess that what really is lacking in the Hegelian speculative development, are two fundamental elements:

1. the eminence of the Unity of Being, Nothing and Becoming as immediate Essence of the Origin and as inner Nature of the manifestation of the Sublime.

2. the need for a privative Nothing in order to entail the actualization of the determinate being, as Ontological Difference between absolute Being and determinate being.

The entire Hegelian exercise that follows is constructed upon a sudden continuity between the eminent instantiation of pure and absolute Being, Nothing and Becoming and the passing into Existence and determinate being. The Hegelian narrative appears to assume precisely what Hegel explicitly pretended: a narrative about God Himself, before the creation of the world (Hegel, 2010 [1832], p. 29).

Another issue is that if Hegel would have postulated the Origin as plentiful in its absolute Immediacy, he would have had to proceed in a preliminary explicit theological path where he would have taken into discussion:

1. the sublimity of the absolutely accomplished Being as the abundance of the unity of the absolute and immediate Multiple and of all its attributes.

2. the metaphysical ontological Essence that couldn't have been the same reflection of the immediate division of Being (in its unbegun Origin), but it would have been the supreme perichoresis of the absolute instances of the exhaustive alterity. In this case the eminent Essence would have had to be established against the speculative Essence of the determinate being, this time as the irreducibility of the eminent Essence to the phenomenality and its laws, just as phenomenality preserved its independence towards the laws of the intellect (Biard, et al., 1983, pp. 205-233).

3. the unity of Becoming would have supported the radical identity of the exceeding Immediacy with its absolute alterity as eschatological revelation of the world of the Concept and of the Idea as concrete experience of the subjective spirit in the life of the explicit manifestation of the Principle - thus mirroring the Concept section of the Science of Logic (Biard, et al., 1987, pp. 16-20 \& sqq.). But in this new occurrence, 
the life of the political and social community and of the State and its institutions would not have had been enough for such ultimative and soteriological experience.

However, we may have some suggestions in other parts of his work that he might have had a few hints also towards such possibilities — as in the fragment about "Love" (Hegel, 1975 [1795], pp. 302-308).

What Hegel's principle of identity lacked, then, is this concreteness and richness of the absolute Undetermined Immediacy. This fundamental privation opened too much his speculative position towards the uncertainty of the speculative aperture and its exhaustiveness which has made his system permeable to the infinite fractionation and unrest of the perpetual speculative turn. In short, instead of maintaining and using his speculative method as an instrument, in certain places of his works Hegel was compelled to change this position for the speculative endeavor into an end in itself, substituting the superrational object that imposed the speculative method, with the method itself. The method, in the speculative endeavor, is coincident with the object, that much is true. But the finality of the subject engaged in this adventure is not actualized in the same way when it reaches the very scope or object of the endeavor, or if he or she engages only into the path or proceeding towards the same object. If the method immediately gives the object, the subject should change his or her behavior. Or else he or she will continue to act inside the premises of the method regardless whether they reached the object or not. In fact, when the object has already been reached, continuing to manifest the speculative method as a critical prevention mode against their own limitation implies that the object has not been effectively reached and that the speculative analysis should continue, never mind the fact that the object has already been manifested in the method and we should concentrate, then, on the object itself since it would always compel us to use at least the speculative in our interaction with it. Instead, at every turn of the exposition the speculative method resumes the same common places of denouncing and speculatively deconstructing the formal thought's confusions in order to transcend them, as if once wouldn't have been enough.

In other words, the speculative, once that it would have attained its own accomplishment of transcending the common mistakes of the formal thinking, would treat its acquired results as already embedded in the philosophical and soteriological attitude and it would change its method into that of theological dogmatics. But we shall explore this possibility in a future study.

\section{ACKNOWLEDGEMENT}

This work was supported by a grant of Ministry of Research and Innovation, CNCS - UEFISCDI, project number PN-III-P1-1.1-PD-2016-0886, within PNCDI III. - Publicarea acestei lucrări este sprijinită de un grant al Ministerului Cercetării și Inovării, CNCS - UEFISCDI, cod proiect PN-III-P1-1.1-PD-2016-0886, în cadrul PNCDI III.

\section{REFERENCE LIST}

Biard, J., Buvat, D., Kervegan, J.-F., Kling, J.-F., Lacroix, A., Lécrivain, A., \& Slubicki, M. (1981). Introduction à la lecture de la Science de la Logique de Hegel. I. L'être. Paris: Éditions Aubier-Montaigne.

Biard, J., Buvat, D., Kervegan, J.-F., Kling, J.-F., Lacroix, A., Lécrivain, A., \& Slubicki, M. (1983). Introduction à la lecture de la Science de la Logique de Hegel. II. La Doctrine de l'Essence. Paris: Éditions Aubier-Montaigne.

Biard, J., Buvat, D., Kervegan, J.-F., Kling, J.-F., Lacroix, A., Lécrivain, A., \& Slubicki, M. (1987). Introduction à la lecture de la Science de la Logique de Hegel. III. La Doctrine du Concept. Paris: Éditions Aubier-Montaigne.

Bowie, A. (1993). Schelling and Modern European Philosophy. An Introduction. London and New York: Routledge.

Hegel, G. W. (1975 [1795]). Early Theological Writings. (T. Knox, \& R. Kroner, Trad.) Philadelphia: University of Pennsylvania Press.

Hegel, G. W. (2010 [1832]). The Science of Logic. (G. d. Giovanni, Ed., \& G. d. Giovanni, Trans.) New York, United States of America: Cambridge University Press.

Hegel, G. W. (2018 [1807]). The Phenomenology of Spirit. (T. Pinkard, Ed., \& T. Pinkard, Trans.) New York, 
United States of America: Cambridge University Press. doi:10.1017/9781139050494

Kant, I. (1998 [1781]). Critique of Pure Reason. (P. Guyer, A. W. Wood, Ed., P. Guyer, \& A. W. Wood, Trad.) Cambridge: Cambridge University Press.

Lacan, J. (1966). Écrits. Paris: Éditions du Seuil.

Lacan, J. (2001). Autres écrits. Paris: Éditions du Seuil.

Léonard, A. (1974). Commentaire littéral de la Logique de Hegel. Paris: J. Vrin.

Lustman, J. (1977). On Splitting. The Psychoanalytic Study of the Child, 32(1), pp. 119-154. doi:10.1080/00797308.1977.11822336

Opiela, S. (1983). Le Réel dans la logique de Hegel: développement et auto-détermination. Paris, France: Beauchesne.

Schelling, F. W. (1994 [1827]). On the History of Modern Philosophy. (A. Bowie, Trad.) Cambridge: Cambridge University Press.

Schlitt, D. M. (2012 [1984]). Hegel's Trinitarian Claim: A Critical Reflection (ed. 2nd). New York: SUNY Press.

Spinoza, B. (2002). Complete Works. (M. L. Morgan, Ed., \& S. Shirley, Trad.) Indianapolis/Cambridge: Hackett Publishing Company, Inc.

Wirth, J. M. (2003). The Conspiracy of Life. Meditations on Schelling and His Time. Albany: State University of New York Press. 